\title{
Flood Insurance - A Key to Recovery
}

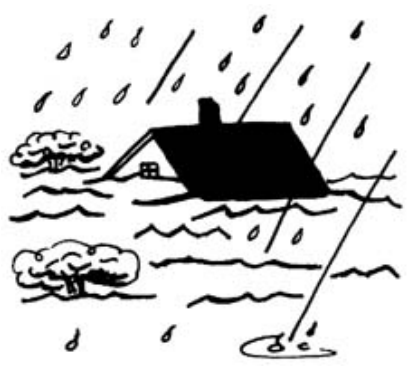

- This publication was written by Regina Fegan and Michael T. Olexa, Food and Resource Economics Department, University of Florida.

- This document, IFAS publication DH0434, was published June 1998 revised May 2003. It is part of The Disaster Handbook, a component of the Comprehensive Disaster Preparedness and Recovery Education Module; General editor: Carol J. Lehtola, Agricultural and Biological Engineering Department, Institute of Food and Agricultural Sciences, University of Florida, Gainesville, Florida 32611.

For information about products and ordering, please visit: $<$ http://disaster.ifas.ufl.edu>.

UF/IFAS Extension publications are available at the EDIS Web site:

$<$ http:/ledis.ifas.ufl.edu>.

- The Institute of Food and Agricultural Sciences is an equal opportunity / affirmative action employer authorized to provide research, educational information, and other services only to individuals and institutions that function without regard to race, color, sex, age, handicap, or national origin. For information on obtaining other extension publications, contact your county Cooperative Extension Service office. Florida Cooperative Extension Service / Institute of Food and Agricultural Sciences / University of

Florida / Christine Taylor Waddill, Dean.
A. What is the National Flood Insurance Program?
B. Why should you get National Flood Insurance?
C. When should you get National Flood Insurance?
D. How do you get National Flood Insurance?

\section{Relying solely on federal disaster assistance is BAD STRATEGY!}

I Federal disaster assistance is only available if a flood is declared a Federal disaster. More than 90 percent of all disasters in the U.S. are not Presidentially declared.

i Disaster aid usually comes in the form of loans, which must be repaid with interest.

$\bigoplus$ Most homeowners' policies do not cover flooding.

Federal flood insurance reimburses you for flood damage! Even if a disaster has not been declared!

\section{A. What is the National Flood Insurance Program?}

The Federal Emergency Management Agency's (FEMA) Federal Insurance Administration makes the National Flood Insurance Program (NFIP) available to residents of communities that adopt and enforce floodplain management ordinances that represent sound land use practices.

It doesn't matter whether your flood risk is high, medium, or low, you can buy flood insurance as long as your community participates in the National Flood Insurance Program. (Go to $<$ http://www.fema.gov/nfip/how.htm $>$ to find out how your community can participate in the NFIP.)
The Disaster Handbook

Institute of Food and Agricultural Sciences

University of Florida
Flood Insurance - A Key to Recovery Section 4.34

Page 1 
And, it's a good idea to buy even in low or moderate risk areas: almost 25 percent of all flood insurance claims come from low- to moderate-risk areas. (Go to $<$ http://www.fema.gov/nfip/prpbroch.htm $>$ to find out about the low-cost policy for homes in low- to moderate-risk areas.

\section{B. Why Should You Get Flood Insurance?}

You don't need to live near water to be flooded. Floods are caused by storms, melting snow, hurricanes, and water backup due to inadequate or overloaded drainage systems, dam or levee failure, etc.

The average flood insurance policy costs:

- About $\$ 300$ a year

- For about $\$ 100,000$ of coverage.

In comparison, a disaster home loan can cost you

- More than $\$ 300$ a month

- For $\$ 50,000$

- Over 20 years.

If you live in a Special Flood Hazard Areas (SFHAs), federally regulated lending institutions will require flood insurance to get secured financing to buy, build, or improve structures. The law requires flood insurance in an amount equal to the outstanding principal balance of the loan, the value of the building, or the maximum limit of coverage available under the Act, whichever is less. It also requires flood insurance to be maintained for the life of the loan.

C. When Should You Get Flood Insurance? PLAN AHEAD! There is usually a 30-day waiting period before the coverage goes into effect.

\section{How Do You Get National Flood Insurance?}

You can buy NFIP flood insurance from private insurance companies and agents; call yours today!

By visiting the following Web site:

The Disaster Handbook Institute of Food and Agricultural Sciences University of Florida
Flood Insurance — A Key to Recovery Section 4.34

Page 2 
This publication is designed to provide accurate, current, and authoritative information on the subject. However, since the laws, regulations, administrative rulings, and court decisions on which it is based are subject to constant revision, portions of this publication could become outdated at any time. This publication is distributed with the understanding that the authors are not engaged in rendering legal advice or opinions, and the information contained herein should not be regarded, or relied upon, as a substitute for legal advice or opinion. For these reasons, the utilization of these materials by any person constitutes an agreement to hold harmless the authors, the Institute of Food and Agricultural Sciences and the University of Florida for any liability claims, damages or expenses that may be incurred by any person as a result of reference to or reliance on the information contained in this fact sheet. $<\mathrm{http}$ ://www.fema.gov/nfipInsurance/companies.jsp $>$

you can locate private insurance companies in your area that, through an agreement with the Federal Insurance Administration, sell and service Federal flood insurance policies. You may also contact your insurance agent or company.

\section{Sources of This Publication}

Federal Emergency Management Agency (FEMA)

Answers to Questions About the National Flood Insurance

Program.

Access on the Web at: <http://www.fema.gov/nfip/qanda.htm>.

Federal Emergency Management Agency (FEMA)

Flood: Are You Protected from the Next Disaster?

Access on the Web at: <http://www.fema.gov/nfip/flood.htm>,

Federal Emergency Management Agency (FEMA)

Nothing Could Dampen the Joy of Home Ownership...Or Could

It?

Access on the Web at: <http://www.fema.gov/nfip/dampen.htm>.

Federal Emergency Management Agency (FEMA)

Things You Should Know About Flood Insurance

Access on the Web at: <http://www.fema.gov/nfip/things.htm>.

Federal Emergency Management Agency (FEMA)

Top 10 Facts Every Consumer Needs to Know About the NFIP Access on the Web at: <http://www.fema.gov/nfip/c_10.htm>.

Federal Emergency Management Agency (FEMA)

What You Need to Know About Federal Disaster Assistance \& National Flood Insurance

Access on the Web at: <http://www.fema.gov/nfip/know.htm>.
The Disaster Handbook

Institute of Food and Agricultural Sciences

University of Florida
Flood Insurance — A Key to Recovery

Section 4.34

Page 3 